\title{
Efficacy evaluation of a commercial neem cake for control of Haematobia irritans on Nelore cattle
}

\author{
Avaliação da eficácia de uma torta comercial de nim para o controle de Haematobia irritans em bovinos Nelore
}

\author{
Ana Carolina de Souza Chagas ${ }^{1 *}$; Márcia Cristina de Sena Oliveira ${ }^{1}$; Rodrigo Giglioti² Fernando Henrique Calura $^{3}$; \\ Jenifer Ferrenzini ${ }^{3}$; Moacir Rossi Forim ${ }^{4}$; Antonio Thadeu Medeiros de Barros ${ }^{5}$ \\ ${ }^{1}$ Laboratório de Sanidade Animal, Embrapa Pecuária Sudeste - CPPSE \\ ${ }^{2}$ Programa de Pós-graduação em Genética e Melhoramento Animal, Universidade Estadual Paulista - UNESP \\ ${ }^{3}$ Centro Universitário Central Paulista - UNICEP \\ ${ }^{4}$ Instituto de Química, Universidade Federal de São Carlos - UFSCar \\ ${ }^{5}$ Embrapa Pantanal - CPAP
}

Received July 6, 2010

Accepted October 22, 2010

\begin{abstract}
Much attention has been given to the development of botanical insecticides to provide effective natural control of cattle ectoparasites without harming animals, consumers, and environment. This study evaluated the efficacy of a commercial neem cake in controlling Haematobia irritans infestation on cattle. The study was conducted at the Embrapa Southeast Cattle Research Center (CPPSE), in São Carlos, SP, Brazil, from April to July 2008. The neem cake mixed in mineral salt in a $2 \%$ concentration was provided to 20 Nelore cows during nine weeks and had its efficacy evaluated by comparison of the infestation level against a control group. Fly infestations were recorded weekly by digital photographs of each animal from both groups and the number of flies was later counted in a computer-assisted image analyzer. Quantification of neem cake components by high-performance liquid chromatography revealed the presence of azadirachtin ( $\left.421 \mathrm{mg} \cdot \mathrm{kg}^{-1}\right)$ and 3-tigloyl-azadirachtol $\left(151 \mathrm{mg} \cdot \mathrm{kg}^{-1}\right)$ in the tested neem cake. Addition of the $2 \%$ neem cake reduced mineral salt intake in about $22 \%$. The $2 \%$ neem cake treatment failed to reduce horn fly infestations on cattle during the 9-week study period.
\end{abstract}

Keywords: Horn fly, azadirachtin, 3-tigloyl-azadirachtol, phytotherapy, plant extract.

\section{Resumo}

Muita atenção tem sido dada ao desenvolvimento de inseticidas vegetais buscando-se um efetivo controle de ectoparasitas de bovinos, sem prejudicar animais, consumidores e meio ambiente. Este estudo, realizado de abril a julho de 2008, na Embrapa Pecuária Sudeste, em São Carlos, SP, Brasil, avaliou a eficácia de uma torta comercial de nim (Azadirachta indica) no controle da mosca-dos-chifres (Haematobia irritans) em bovinos. A torta de nim, misturada ao sal mineral na concentração de $2 \%$, foi fornecida a 20 vacas Nelore, durante nove semanas, e sua eficácia foi monitorada através de contagens semanais nos grupos tratado e controle. Infestaçóes individuais foram registradas por meio de fotos digitais em todos os animais de ambos os grupos, e o número de moscas foi, posteriormente, quantificado com o auxílio de um sistema de análise de imagem computadorizado. A quantificação dos componentes da torta de nim, por cromatografia líquida, revelou a presença de azadiractina $\left(421 \mathrm{mg} \cdot \mathrm{kg}^{-1}\right)$ e 3-tigloyl-azadirachtol $\left(151 \mathrm{mg} \cdot \mathrm{kg}^{-1}\right)$. A adição da torta de nim a $2 \%$ reduziu o consumo de sal mineral em cerca de $22 \%$. O tratamento com torta de nim a $2 \%$ náo reduziu as infestaçôes por mosca-dos-chifres em bovinos durante as nove semanas do estudo.

Palavras-chave: Mosca-dos-chifres, azadiractina, 3-tigloyl-azadirachtol, fitoterapia, extrato vegetal.

\footnotetext{
${ }^{*}$ Corresponding author: Ana Carolina de Souza Chagas

Laboratório de Sanidade Animal, Embrapa Pecuária Sudeste, Rod. Washington

Luiz, Km 234, CP 339, CEP 13560-970 São Carlos - SP, Brazil;

e-mail: carolina@cppse.embrapa.br
} 


\section{Introduction}

The horn fly Haematobia irritans (Diptera: Muscidae) was first reported in Brazil by Valério and Guimarães (1983) and later dispersed throughout South America. Current estimates on annual economic impacts caused by this fly to cattle industry in Brazil may reach US\$ 865 million (BIANCHIN et al., 2006).

Control of horn flies relies routinely on chemical products and, as a predictable consequence, this fly has acquired resistance to most commonly used drug classes. The indiscriminate use of synthetic pyrethroids for controlling $H$. irritans during the last two decades in Brazil led to selection of resistant populations to insecticides of this class all over the country (GUGLIELMONE et al., 2001, OLIVEIRA et al., 2006; BARROS et al., 2007).

The use of synthetic pesticides can be harmful to the environment as well as animal and human health (HABLUETZEL et al., 2007), and the quest for alternative options has become an urgent need. Among potential alternatives, the use of plant extracts has been considered a promising option to reduce pesticide use in controlling livestock parasites.

The neem tree (Azadirachta indica A. Juss, Meliaceae) produces azadirachtin, a tetranortriterpenoid with several biological activities against insects as well as low residual effects (GUERRINI; KRITICOS, 1998; KRAUS, 2002; MORGAN, 2004). Besides azadirachtin, other 35 substances present in the neem tree have been classified as biologically actives. This chemical diversity can be an important tool to slow the development of resistance by parasites (MULLA; SU, 1999), as well as to reduce the impact of synthetic pesticides on natural enemies, such as parasitoids, predators, and microorganisms, which contribute for reducing fly populations (MOCHI et al., 2010).

In recent years the number of commercial neem products, particularly for control of $H$. irritans and Rhipicephalus (Boophilus) microplus, has increased in the Brazilian insecticide market as well as their use. However, despite the increasing adoption of such control measures, no scientific evidence of their efficacy under field conditions is available. The present study aimed to evaluate the efficacy of a commercial neem cake for control of horn fly infestations in Nelore cattle in Brazil.

\section{Material and Methods}

\section{Location}

The experiment was carried out at Embrapa Southeast Cattle Research Center (CPPSE), located in Sáo Carlos, SP, Brazil ( $21^{\circ} 57^{\prime} 42^{\prime \prime} \mathrm{S}$ and $47^{\circ} 50^{\prime} 28^{\prime \prime} \mathrm{W}$, and 860 m.a.s.l.) from April to July 2008. Daily climatic data were recorded at the local weather station during the study.

\section{Animal treatments and fly counts}

The study design and conduction were in accordance with the recommendations of Regulation No. 48 from the Brazilian Ministry of Agriculture, Livestock and Food Supply for testing drugs against Haematobia irritans (BRASIL, 1997).
Forty Nelore cows, aged 7 to 10 years and averaging $480 \mathrm{~kg}$, were divided into two similar groups based on pre-treatment fly counts. The 20 cows of the treated group received a mixture of commercial neem cake at $2 \%$ in mineral salt, as recommended by manufacturer. The remaining 20 cows were kept untreated (control group) and received mineral salt only. These experimental herds were maintained on noncontiguous 20 ha pastures (about $1 \mathrm{~km}$ apart) of Brachiaria decumbens with water ad libitum.

Two pre-treatment fly counts were carried out in Weeks -2 and -1 to allow animal ranking and group separation. After the beginning of the experiment, the number of flies was weekly counted until Day 63 (Weeks 0 to 8) on all animals from both groups. Each experimental group was brought to the chute separately and the cows were immobilized to allow flies land on their backs. Their dorsal region was then photographed with a digital camera (Sony Cyber-shot) and the number of flies was counted in the laboratory with the aid of Microsoft Paint Brush software.

The intake of neem cake + mineral salt mixture was measured in both groups. The neem-salt mixture was weakly produced and supplied. Both salt and mixture consumption was estimated by dividing the total quantity supplied by the number of animals in each group, after subtracting the amount left.

\section{Quantification of azadirachtin and 3-tigloyl-azadirachtol}

The commercial neem cake tested in this study consisted of compressed and ground neem seeds, obtained after the industrial production of neem oil. Sample preparation and quantification of the active compounds azadirachtin and 3-tigloyl-azadirachtol in the cake, before its mixture with mineral salt, were done by high-performance liquid chromatography (HPLC) according to Forim et al. (2010). The method's selectivity was determined by comparing the chromatograms of the extract against standards for azadirachtin and 3-tigloyl-azadirachtol, and the identification was done by comparing retention time of the peaks (Figure 1).

Product efficacy in reducing horn fly infestation on cattle was calculated by the following formula (Equation 1):

$$
\text { Efficacy }(\%)=\frac{\begin{array}{c}
\text { mean number } \\
\text { of flies in } \\
\text { control group }
\end{array} \quad \begin{array}{c}
\text { mean number } \\
\text { of flies in } \\
\text { treated group }
\end{array}}{\begin{array}{l}
\text { mean number of flies } \\
\text { in control group }
\end{array}} \times 100
$$

The results were analyzed by Tukey's test with average comparison.

\section{Results}

From April to July the mean temperature was $19.2{ }^{\circ} \mathrm{C}$ ( 18.4 to $21.7^{\circ} \mathrm{C}$ ), mean relative humidity was $68 \%$ (56 to $74 \%$ ) and total precipitation was $203.8 \mathrm{~mm}$ (Figure 2).

Maximum mean group infestation was 86.3 flies/animal (Week -1) while individual infestations reached 330 flies/animal. Horn fly numbers on animals decreased along the experiment (Figure 3). The percentages of reduction from Week -2 to 8 
were $-1.5,7.5,20.6,0.0,-68.9,-37.8,26.0,-26.3,5.4,5.0$ and $-157.1 \%$, respectively. Statistically significant differences $(\mathrm{p}<0.0001)$ were found in the fly counts among weeks.

The average daily consumption of the neem-salt mixture per animal was $47 \mathrm{~g}$ (about $940 \mathrm{mg}$ of neem cake) in the treated group and about $60 \mathrm{~g}$ of the mineral salt in the control group. The HPLC quantification of neem cake compounds revealed the presence of azadirachtin ( $\left.421 \mathrm{mg} \cdot \mathrm{kg}^{-1}\right)$ and 3-tigloyl-azadirachtol $\left(151 \mathrm{mg} \cdot \mathrm{kg}^{-1}\right)$. Thus, treated animals ingested approximately $0.396 \mathrm{mg}$ of azadirachtin per day.

\section{Discussion}

Climatic parameters, particularly temperature and rainfall, declined along the study period, which was considered typical for the region. Horn fly numbers present on animals gradually reduced along the study. Because infestation declined on both treated and control animals and no significant difference on fly numbers was found between groups, reduction in fly numbers was not attributed to the treatment itself instead it was associated with unfavorable weather conditions. This seasonal behavior of horn fly populations agrees with other studies conducted in the State of São Paulo, in which population peaks occurred in spring and summer and fly numbers dropped in winter (FRAGA et al., 2005; LIMA et al., 2003).

Few studies have been conducted to evaluate the efficacy of A. indica on livestock ectoparasites. Furthermore, application mode as well as tested plant parts and active ingredient concentrations might have some different results among studies, thus making comparisons difficult. Also, phytochemical analysis of the plant material tested is often lacking in most studies. The control efficacy and selectivity of commercial neem formulations available in the Brazilian market are highly variable since there is no standardization of the azadirachtin content (BRITO et al., 2006).

In the present study, addition of just $2 \%$ neem cake to the mineral salt reduced salt ingestion by $22 \%$ in the treated group when compared to salt intake in the control group. The low palatability of $A$. indica has been previously reported (CHAGAS; VIEIRA, 2007; CHAGAS et al., 2008). Such palatability problem was also noticed by Miller and Chamberlain (1989) when $1.5 \%$ of ground neem seed mixed into feed was provided to steers; however, because feed intake was normal in a $0.8 \%$ seed mixture, the authors concluded that the palatability upper limit for ground neem seed seemed to be about $1 \%$.

Orally administered ground neem seed, neem extract, and emulsifiable neem formulation highly reduced adult horn fly emergence in manure from treated animals (MILLER; CHAMBERLAIN, 1989). When steers ingested about $2 \mathrm{~g}$ of ground neem seed/day, a daily consumption of about $4.9 \mathrm{mg}$ of azadirachtin, treatment efficacy reached $97 \%$ at Day 3 after treatment and completely inhibited emergence when higher doses were provided. In the present study, which followed the product manufacturer recommendations, about half of the quantity of the neem material ( $940 \mathrm{mg}$ of neem cake) was ingested by the animals when compared to that consumed at lower concentration

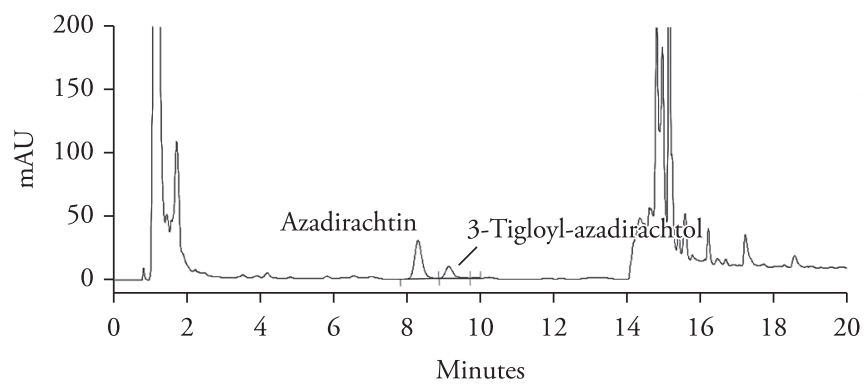

Figure 1. Chromatogram of the analysis of azadirachtin and 3-tigloyl-azadirachtol in methanol extract of a commercial neem (Azadirachta indica) cake, São Carlos, SP, Brazil.

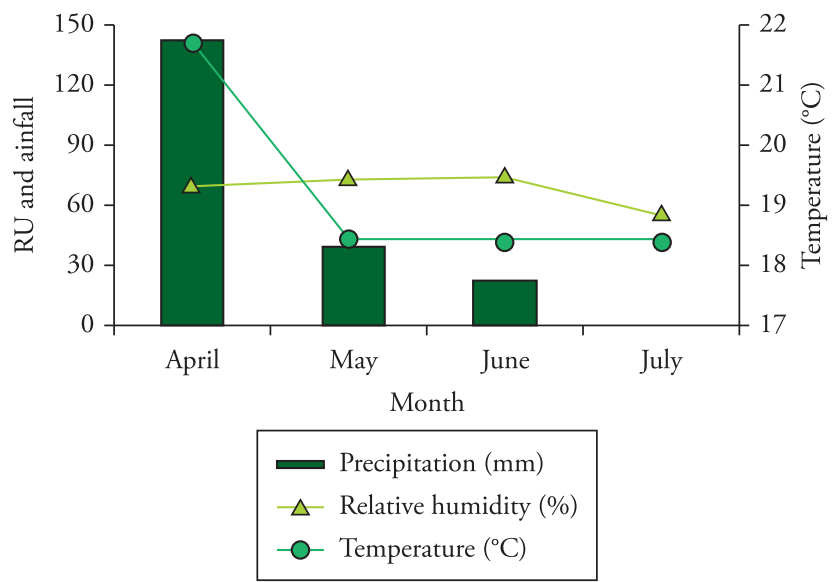

Figure 2. Mean temperature $\left({ }^{\circ} \mathrm{C}\right)$, mean relative humidity $(\%)$ and total precipitation ( $\mathrm{mm}$ ) from April to July 2008 at the weather station of the Embrapa Southeast Cattle Research Center, São Carlos, SP, Brazil.

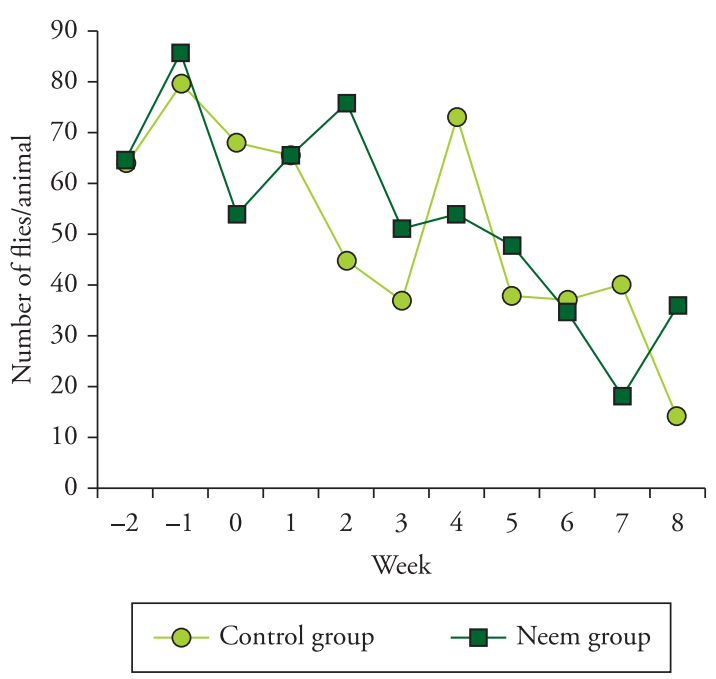

Figure 3. Mean number of Haematobia irritans before treatment (Week -2 and -1) and during treatment (Week 0-8) of cattle with a commercial neem cake, conducted from April to July 2008 in São Carlos, SP, Brazil. 
(2 $\mathrm{g}$ of ground neem seed) tested in Miller and Chamberlain study (1989). Furthermore, daily consumption of the active ingredient azadirachtin in the present study $(0.396 \mathrm{mg} / \mathrm{animal}$ or $0.825 \mu \mathrm{g} \cdot \mathrm{kg}^{-1}$ of body weight) was much lower than that ingested in the mentioned study ( $4.9 \mathrm{mg} / \mathrm{animal}$ or $24.5 \mu \mathrm{g} \cdot \mathrm{kg}^{-1}$ of body weight). Lower ingestion of azadiracatin may explain the lack of efficacy showed by the neem cake when used as indicated in the product label. Based on results from Miller and Chamberlain (1989), intake of azadirachtin should be at least 12 times higher in the present study to achieve effective horn fly control. However, it should be taken into account that increasing concentration of neem cake in the mixture as well as the quantity of the mixture available to the animals may have negative implications on animal consumption and treatment costs.

In addition, some compounds of $A$. indica seem to have a short environmental stability, lasting at most 4 to 8 days because degradation by ultraviolet light, $\mathrm{pH}$ reduction and rain (GUERRINI, 2000; MOSSINI; KEMMELMEIER, 2005). Low stability of neem may require additional treatments to achieve a longer control period that may preclude its use in several situations. The potential use of azadirachtin for horn fly control has been recognized if the stability problem can be solved (MILLER; CHAMBERLAIN, 1989).

The antiparasite activity of $A$. indica has been particularly attributed to triterpenoid azadirachtin. The presence of this active ingredient greatly varies along the plant and its concentration may vary from 5.9 in leaves to $248.5 \mathrm{mg} . \mathrm{kg}^{-1}$ in seeds (SUNDARAM, 1996). The quantification of azadirachtin in the neem cake tested in this study $\left(421 \mathrm{mg} \cdot \mathrm{kg}^{-1}\right)$ indicated that the neem material supplied to the animals was of excellent quality, containing $41 \%$ more azadirachtin than that detected by Sundaram (1996). Nevertheless, the product failed to reduce horn fly population on the animals treated under field conditions, although the product advertisement claims that it is effective at $2 \%$ or less in reducing fly infestations and results can be seen in few days.

The neem cake has been evaluated as an alternative method to increase livestock productivity by reducing parasite populations on various animals, such as hogs, chickens and sheep (MUSALIA et al., 2000; USMAN et al., 2005; ODUNSI et al., 2009). However, neem has an unpleasant taste and smell, limiting its supply to animals since its use above the upper limit of palatability can inhibit feeding. Therefore, studies have tested alternative ways to administrate neem cake and improve its consumption assuring adequate weight gains (ODUNSI et al., 2009).

In conclusion, neem cake at $2 \%$ added to mineral salt was not effective in controlling horn fly infestation on cows during the two-month treatment. Thus, the product used as recommended by the manufacturer failed to achieve an effective reduction in the number of flies.

\section{Acknowledgements}

The authors wish to thank CPPSE staff for supporting field and laboratory activities.

\section{References}

BARROS, A. T. M.; GOMES, A.; KOLLER, W. W. Insecticide susceptibility of horn flies, Haematobia irritans (Diptera: Muscidae), in the state of Mato Grosso do Sul, Brazil. Revista Brasileira de Parasitologia Veterinária, v. 16, n. 3, p. 145-151, 2007.

BIANCHIN, I.; KOLLER, W. W.; DETMANN, E. Sazonalidade de Haematobia irritans no Brasil Central. Pesquisa Veterinária Brasileira, v. 26, n. 2, p. 79-86, 2006.

BRASIL. Regulamento técnico para licenciamento e ou renovaçáo de licença de produtos antiparasitários de uso veterinário. Portaria Ministerial $\mathrm{n}^{\circ}$ 48, de 12 de maio de 1997. 16 p. Disponível em: <http://extranet.agricultura.gov.br/sislegis-consulta/servlet/ VisualizarAnexo?id=2118>. Acesso em: 17 jun. 2010.

BRITO, H. M. et al. Toxicidade de formulaçóes de nim (Azadirachta indica A. Juss.) ao ácaro-rajado e a Euseius alatus De Leon e Phytoseiulus macropilis (Banks) (Acari: Phytoseiidae). Neotropical Entomology, v. 35, n. 4, p. 500-505, 2006.

CHAGAS, A. C. S. et al. Anthelmintic efficacy of neem (Azadirachta indica A. juss) and the homeopathic product Fator Vermes in Morada Nova sheep. Veterinary Parasitology, v. 151, n. 1, p. 68-73, 2008.

CHAGAS, A. C. S.; VIEIRA, L. S. Ação de Azadirachta indica (Neem) em nematódeos gastrintestinais de caprinos. Brazilian Journal of Veterinary Research and Animal Science, v. 44, n. 1, p. 49-55, 2007.

FORIM, M. R. et al. Chemical characterization of Azadirachta indica grafted on Melia azedarach and analyses of azadirachtin by HPLC-MSMS (SRM) and meliatoxins by MALDI-MS. Phytochemical Analysis, v. 21, n. 4, p. 363-373, 2010.

FRAGA, A. B. et al. Genetic analysis of the infestation of females of the Caracu cattle breed by horn fly (Haematobia irritans irritans) (L.) (Diptera, Muscidae). Genetics and Molecular Biology, v. 28, n. 2, p. 242-247, 2005.

GUERRINI, V. H. Effect of azadirachtin on Damalinia ovis in sheep. Online Journal of Veterinary Research, v. 4, n. 3, p. 133-138, 2000.

GUERRINI, V. H.; KRITICOS, C. M. Effects of azadirachtin on Ctenocephalides felis in the dog and the cat. Veterinary Parasitology, v. 74, n. 2-4, p. 289-297, 1998.

GUGLIELMONE, A. A. et al. Toxicity of cypermethrin and diazinon to Haematobia irritans (Diptera: Muscidae) in its American southern range. Veterinary Parasitology, v. 101, n. 1, p. 67-73, 2001.

HABLUETZEL, A. et al. Impact of the botanical insecticide Neem Azal on survival and reproduction of the biting louse Damalinia limbata on angora goats. Veterinary Parasitology, v. 144, n. 3-4, p. 328-337, 2007.

KRAUS, W. Biologically active ingredients. In: SCHMUTTERER, H. (Ed.). The neem tree: sources of unique natural products for integrated pest management, medicine, industry and other purposes. $2^{\text {nd }} \mathrm{ed}$. Mumbai: Neem Foundation, 2002. p. 39-110.

LIMA, L. G. F.; PERRI, S. H. V.; PRADO, A. P. Variation in population density of horn flies (Haematobia irritans irritans) (L.) (Diptera: Muscidae) in Nellore cattle (Bos indicus). Veterinary Parasitology, v. 117, n. 4 , p. 309-314, 2003.

MILLER, J. A.; CHAMBERLAIN, W. F. Azadirachtin as a larvicide against the horn fly, stable fly, and house fly (Diptera: Muscidae). Journal of Economic Entomology, v. 82, n. 5, p. 1375-1378, 1989. 
MOCHI, D. A. et al. Efficiency of entomopathogenic fungi in the control of eggs and larvae of the horn fly Haematobia irritans (Diptera: Muscidae). Veterinary Parasitology, v. 167, n. 1, p. 62-66, 2010.

MORGAN, E. D. The place of neem among modern natural pesticides. In: KOUL, O.; WAHAB, S. (Ed.). Neem: today and in the new millennium. Boston: Kluwer Academic Publishers, 2004. p. 21-32.

MOSSINI, S. A. G; KEMMELMEIER, C. A árvore Nim (Azadirachta indica A. Juss): Múltiplos Usos. Acta Farmacêutica Bonaerense, v. 24, n. 1, p. 139-148, 2005.

MULLA, S.; SU, T. Activity and biology effects of neem products against arthropods of medical and veterinary importance. Journal of the American Mosquito Control Association, v. 15, n. 2, p. 133-152, 1999.

MUSALIA, L. M. et al. Urea-treated neem (Azadirachta indica A. juss) seed kernel cake as a protein supplement for lambs. Small Ruminant Research, v. 35, n. 2, p. 107-116, 2000.
ODUNSI, A. A. et al. Neem (Azadirachta indica) seed cake in the diets of Cockerel chickens. International Journal of Poultry Science, v. 8, n. 1,p. 47-51, 2009.

OLIVEIRA, A. A. A. et al. Suscetibilidade da mosca-dos-chifres (Haematobia irritans) a inseticidas nos tabuleiros costeiros de Alagoas, Bahia e Sergipe. Revista Brasileira de Parasitologia Veterinária, v. 15, n. 2, p. 65-70, 2006.

SUNDARAM, K. M. S. Azadirachtin biopesticide: a review of studies conducted on its analytical chemistry, environment behavior and biological effects. Journal of Environmental Science and Health, v. 31, n. 4, p. 913-948, 1996.

USMAN, L. A. et al. The extraction of proteins from the neem seed (Indica azadirachta A. Juss). African Journal of Biotechnology, v. 4, n. 10, p. 1142-1144, 2005.

VALÉRIO, J. R.; GUIMARÃES, J. H. Sobre a ocorrência de uma nova praga, Haematobia irritans (L.) (Diptera: Muscidae), no Brasil. Revista Brasileira de Zoologia, v. 1, n. 4, p. 417-418, 1983. 